Research Article

\title{
Oral versus Vaginal Misoprostol for Labour Induction : A Comparative Study
}

\section{Misoprostol Oral versus Pervaginam untuk Induksi Persalinan : Suatu Studi Komperatif}

\author{
Eka P Mahacakri', Nuswil Bernolian1, Wim Pangemanan1, Theodorus ${ }^{2}$
}

${ }^{1}$ Department of Obstetrics and Gynecology

${ }^{2}$ Public Health and Research Unit

Faculty of Medicine Universitas Sriwijaya/

Dr. Mohammad Hoesin Hospital

Palembang

\begin{abstract}
Objective: To compare the efficacy and safety of hourly titrated oral misoprostol in solution (OMS) with vaginal misoprostol (PV) for labor induction.

Methods: Randomized Controlled Trial (RCT), double blind-add on the study was conducted from January-November 2016 in delivery ward of Moh. Hoesin general hospital. Women $\geq 30$ weeks of gestation with an unfavorable cervix (Bishop score $\leq 6$ ) and an indication for labor induction were randomly assigned to receive titrated oral or vaginal misoprostol. The OMS group received a basal unit of $20 \mathrm{ml}$ misoprostol solution $(1 \mu \mathrm{g} / \mathrm{ml})$ every 1 hour for four doses and then were titrated against individual uterine response. In the absence of regular uterine contractions, the dose was increased to $40 \mathrm{ml}$ hourly for four doses and then $60 \mathrm{ml}$ for four doses. The vaginal group received $25 \mu \mathrm{g}$ every 4 hours until attaining a more favorable cervix for three doses. All the subjects received amylum placebo. In labor within 12 hours was the primary outcome.

Results: A total of 30 women were enrolled in this study. One subject in the OMS group was dropped out due to eclamptic seizure. The average interval from induction until in labour in OMS group was $5.75 \pm 3.14$ hour and $6.60 \pm 4.46$ hour in PV group $(p=0.56)$. In labour stage was achieved within 12 hours in 14 women $(100 \%)$ in OMS group and 14 women $(93.3 \%)$ in PV group $(\mathrm{p}=1.00)$. Vaginal delivery was achieved within 24 hours in 13 women $(92.9 \%)$ in OMS group and 15 women $(100 \%)$ in PV group. The incidence of uterine hyperstimulation/ tachysystolic was $7.1 \%$ in OMS group compared with 13.3\% in PV group. Fetal distress was found only 1 case $(7.1 \%)$ in OMS group. There was no difference in the maternal and neonatal outcome of labor in both the groups.
\end{abstract}

Conclusion: Oral titrated in solution, and vaginal route of administration of misoprostol for induction of labour are equally effective and safe.

[Indones J Obstet Gynecol 2018; 6-2: 89-97]

Keywords: hourly titrated oral misoprostol in solution, oral misoprostol, randomized controlled trial, vaginal misoprostol

\begin{abstract}
Abstrak
Tujuan: Membandingkan efektivitas dan keamanan pemberian larutan misoprostol titrasi peroral/ titrated oral misoprostol in solution (OMS) dan misoprostol pervaginam (PV) untuk induksi persalinan.

Metode: Randomized Controlled Trial (RCT), double blind-add on dilakukan Januari-November 2016 di kamar bersalin RSUP Dr. Moh. Hoesin Palembang. Terdapat 30 subjek wanita hamil dengan usia gestasi $\geq 30$ minggu dan skor Bishop $\leq 6$ yang memenuhi indikasi induksi persalinan; selanjutnya dirandomisasi menjadi 2 kelompok, yaitu OMS dan PV. Subjek pada kelompok OMS menerima misoprostol peroral $20 \mathrm{ml} / \mathrm{jam}(1 \mu \mathrm{g} / \mathrm{ml})$ sebanyak 4 dosis. Bila kontraksi uterus yang regular belum timbul, dosis dinaikkan menjadi $40 \mathrm{ml} / j a \mathrm{~m} \mathrm{se}-$ banyak 4 dosis. Bila kontraksi regular belum timbul, dosis dinaikkan menjadi $60 \mathrm{ml} / \mathrm{jam}$ sebanyak 4 dosis. Subjek pada kelompok PV menerima misoprostol pervaginam $25 \mu \mathrm{g} / 4$ jam sebanyak 3 dosis. Setiap subjek juga menerima plasebo amilum. Parameter keberhasilan penelitian adalah keberhasilan mencapai inpartu $\leq 12$ jam.
\end{abstract}

Hasil: Dari 30 subjek, 1 orang pada kelompok OMS drop out dari penelitian karena eklampsia berulang. Rerata interval induksi-inpartu pada kelompok OMS 5,75士3,14 jam, sedangkan kelompok PV $6,60 \pm 4,46$ jam $(p=0,56)$. Sebanyak 14 subjek (100\%) pada kelompok OMS dan 14 subjek $(93,3 \%)$ pada kelompok PV mencapai inpartu $\leq 12$ jam $(p=1,00)$. Partus pervaginam $\leq 24$ jam dicapai 13 subjek $(92,9 \%)$ pada kelompok OMS dan 15 subjek (100\%) pada kelompok PV ( $p=0,48)$. Kasus hiperstimulasi/takisistolik uterus ditemukan pada 1 subjek $(7,1 \%)$ pada kelompok OMS dan 2 subjek $(13,3 \%)$ pada kelompok PV. Komplikasi gawat janin ditemukan pada 1 subjek $(7,1 \%)$ pada kelompok OMS. Tidak ditemukan perbedaan bermakna luaran maternal dan neonatus pada kedua kelompok.

Kesimpulan: Larutan misoprostol titrasi peroral memiliki efektivitas dan keamanan yang sama dengan misoprostol pervaginam untuk induksi persalinan.

[Maj Obstet Ginekol Indones 2018; 6-2: 89-97]

Kata kunci: larutan misoprostol titrasi oral perjam, misoprostol peroral, misoprostol pervaginam, uji klinik acak berpembanding

Correspondence: Eka P Mahacakri, putrimahacakri@yahoo.co.id

\section{INTRODUCTION}

Induction of labor is defined as the initiation process of uterine contractions with the help of medical pharmacology or medical action before the onset of spontaneous parturition. ${ }^{1}$ Approximately
$20 \%$ of births in the United States and Britain begins with induction of labor, whereas the incidence of labor induction in Africa and Asia are $4.4 \%$ and $12.1 \%$ of all deliveries, respectively. This proportion will continue to increase significantly almost several years. ${ }^{2-4}$ 
Misoprostol is a synthetic analog of prostaglandin E1 that is inexpensive, stable at room temperature, easily stored, and simple in usage for cervical ripening and induction of labor. However, misoprostol can cause fetal distress due to uterine hyperstimulation or tachysystole uterus. To avoid hyperstimulation or tachysystole uterus and to shorten the induction interval up to labor, misoprostol should be given in small, effective doses, in a high frequency, and titrated according to uterine response. Oral titrated misoprostol solution administration or oral misoprostol in solution (OMS) fulfilled all aforementioned criteria. In addition, divided doses of misoprostol proved to be disadvatageous due to a difficult and imprecise tablet cutting, rendering the dosage to be inappropriate. OMS administration does not only allow the proper dosage, but misoprostol can remain active in the solution for 24 hours. ${ }^{5}$

Cheng, et al. compared the efficacy and safety of OMS and vaginal misoprostol for induction of labor in pregnant women 34-42 weeks with a Bishop score $\leq 6$. OMS were given with an initial dose of $20 \mathrm{mcg} /$ hour and repeated for every hour until adequate uterine contractions were achieved. When the contractions are not adequate after four times of administration, the dose was increased to $40 \mathrm{mcg} /$ hour and repeated every hour until adequate contraction, with a maximum of 4 doses. When the contractions were not adequate after 8 hours from the start of induction, then the dose was increased to $60 \mathrm{mcg} /$ hour until adequate uterine contractions were achieved with a maximum of 4 doses. If the patient has become in labor, then misoprostol is stopped. When the contractions become inadequate before the active phase of labor, then the introduction of OMS can be repeated, starting at a dose of $10 \mathrm{mcg} /$ hour and can be raised to $20 \mathrm{mcg} /$ hour, or up to $40 \mathrm{mg} /$ hour based on the response of the uterus to achieve adequate uterine contractions. Delivery within 24 hours was achieved in $94.1 \%$ of the 101 women who were randomly assigned oral titrated misoprostol solution, compared with $53.8 \%$ of the 106 women given misoprostol vaginally $(p=0.01)$. No women of the OMS group developed uterine hyperstimulation, while $11.3 \%$ in the vaginal misoprostol group did. Although more women experienced nausea in the OMS group (10.9\%), the newborn Apgar score in this group is better ( $>7$ at 1 minute first) than the vaginal group. Cheng, et al. concluded that low doses of titrated misoprostol are associated with a low incidence of uterine hyperstimulation and cesarean section compared with vaginal misoprostol in women with the immature cervix. $^{6}$ In another literature, Cheng concluded OMS is more effective and superior to vaginal misoprostol. By administering OMS, the rate of vaginal delivery becomes higher which decreases the rate of cesarean section. ${ }^{7}$

This study aims to compare the efficacy and safety of oral titrated misoprostol solution (OMS) with vaginal misoprostol (per vaginal misoprostol/ $\mathrm{PV}$ ) in women undergoing labor induction.

\section{METHOD}

This study was a Randomized Controlled Trial (RCT), double-blind, add-on study and had received ethics approval from the Ethics Committee of Dr. Moh. Hoesin Hospital Palembang. The study involved 30 pregnant women who meet the inclusion criteria during the period from January to November 2016. Inclusion criteria for the study were pregnant women $\geq 30$ weeks, fulfilling an indication of induction of labor, a single live fetus pregnancy, Bishop score $\leq 6$, cephalic presentation, normal fetal heart rate patterns, and willing to participate in the study by signing a letter of approval (informed consent). Exclusion criteria included pregnant women with contraindications of vaginal delivery, previous cesarean section, a history of surgery on the uterus, intrauterine fetal death, parity $>5$, the presence of adequate uterine contractions, and abnormal fetal heart rate patterns or fetal distress. Drop out criteria were a history of allergy to misoprostol; patients experience side effects that heavy drug misoprostol (adverse effects), such as anaphylactic shock, imminent uterine rupture and uterine rupture; additional diagnoses that can stop the study procedures (eg, eclampsia, impending eclampsia, HELLP syndrome, and so on, which leads to the abdominal termination); or the patient does not comply with the study protocol. Withdrawal criteria were patients who decide to stop participating in the study on their own without any coercion.

The samples were divided into two groups derived from simple randomization using randomization tables. At the titrated oral misoprostol group (OMS), a solution of misoprostol was given orally according to the study protocols, and one placebo tablet which will be divided into 
$1 / 8$ parts and administered vaginally in the posterior fornix according to the study protocols. In the group of vaginal misoprostol (PV), one placebo tablet was dissolved in $200 \mathrm{ml}$ of water in a glass and administered according to the appropriate protocol, and one tablet of misoprostol $200 \mathrm{mcg}$ which will be divided into $1 / 8$ parts $(25 \mathrm{~g}$ ) and administered in the posterior vaginal fornix. Regimens in the two groups of these samples were administered without the knowledge of researchers (blinded). Material samples have been coded "OMS" or "PV" and put in a sealed envelopes which have been given a random number based on the randomization tables by individuals not directly involved in the study. Before the envelope is closed and sealed, the envelope code is recorded on a special sheet and stored separately in a sealed envelope to be opened at the time of data analysis is complete. Researchers and patients did not know the contents of the drug given to the patient.

Misoprostol effectiveness was assessed by achieving successful in labour $\leq 12$ hours after induction began. OMS and PV safety was assessed by observing drug side effects in both maternal and neonatal outcomes. Failed induction was defined as failure to achieve inabour after 12 hours from the start of administration of misoprostol. Uterine hyperstimulation was defined as the presence of excessive uterine contraction with fetal heart rate abnormalities. Changes in fetal heart rate were defined as persistent decelerations, tachycardia, or a decrease in short-term variability. Tachysy stole uterus was defined as the presence of uterine contractions $>5$ times within 10 minutes, which lasted an average of $>30$ minutes without changes in fetal heart rate.

In OMS protocol, one tablet misoprostol (200 $\mu \mathrm{g}$ ) was dissolved in $200 \mathrm{ml}$ water in a medical measurement bottle and mixed evenly. Misoprostol solution should be used within 24 hours after dissolved. OMS was given with an initial dose of $20 \mathrm{ml} /$ hour and repeated every hour until adequate uterine contractions were achieved. When the contractions did not occur or not adequate after four times of administration, the dose was increased to $40 \mathrm{ml} /$ hour and repeated every hour until adequate contractions were achieved, with a maximum of 4 doses. When the contractions were not adequate after 8 hours from the start of induction, then the dose was increased to $60 \mathrm{ml} /$ hour until adequate uterine contractions were achieved with a maximum of 4 doses. Adequate uterine contractions were defined as the presence of three or more uterine contractions in a 10-minute period with a duration $\geq 30$ seconds. ${ }^{7}$

When adequate uterine contractions have been achieved in 1 hour, misoprostol was subsequently terminated. If the patient has reached in labour, then misoprostol is stopped. When the contractions become inadequate after parturients entered labour, acceleration with oxytocin is possible to administer at least 2 hours after the last administration of misoprostol. Acceleration of labor is achieved with oxytocin 5 IU mixed in 500 ccs of Ringer Lactate. During the first 15 minutes, oxytocin is given ten drops/min, then increased five drops every 15 minutes until the adequate contraction is reached or a maximum of 40 drops/minute. If the Bishop score has reached $\geq 9$, amniotomy may be done according to the doctor's discretion. If there is a failed induction, parturients are managed by standard procedure at the Obstetrics and Gynecology Department of Dr. Moh. Hoesin Hospital Palembang.

In PV protocol, the initial dose of $25 \mu \mathrm{g}$ vaginal misoprostol is administered in the posterior vaginal fornix. This dose can be repeated every 4 hours to achieve adequate uterine contractions. Adequate uterine contractions were defined as the presence of three or more uterine contractions in a 10 -minute period with a duration $\geq 30$ seconds. When adequate uterine contractions have been achieved in 1 hour, then misoprostol is subsequently terminated. If the patient has reached in labour, then misoprostol is stopped. When the contractions become inadequate after parturients entered labour, acceleration with oxytocin is possible to administer at least 2 hours after the last administration of misoprostol. If the Bishop score has reached $\geq 9$, amniotomy may be done according to the doctor's discretion. If there is a failed induction, parturients are managed by standard procedure at the Obstetrics and Gynecology Department of Dr. Moh. Hoesin Hospital, Palembang, Indonesia.

Fetal heart rate and uterine contractions are closely monitored using cardiotocography from the beginning of induction until delivery. Data were analyzed using SPSS 18. Dichotomous variables were compared between the two groups using Chi-square test, whereas continuous variables were compared using the Student t-test. A p 
value less than 0.05 was considered as statistically significant.

\section{RESULTS}

A total of 30 subjects were divided into two groups; the OMS (15 pregnant women who received induction treatment with oral titrated misoprostol solution and vaginal placebo) and PV groups (15 pregnant women who received induction treatment with vaginal misoprostol and placebo oral titration solution). After follow-up, there is one subject on which the OMS group who dropped out because of recurrent eclamptic seizures.

Table 1 shows the demographic characteristics of the subjects and indications of induction of labor. No significant difference was found between the demographic characteristics of subjects in both groups. Highest indication of induction in both groups was preeclampsia. However, the numbers of subjects with pre-eclampsia were higher in PV group compared to the OMS group.

The average interval from induction (starting after the first dose of misoprostol) until in labour in the OMS group was $5.75 \pm 3.14$ approximately 60 minutes faster than the $6.60 \pm 4.46$ hours found in the PV group. The average induction to delivery interval occurs more quickly in the OMS group $(10.11 \pm 6.17$ hours) than the PV group (11.33 \pm 6.24 hours). However, statistical analysis revealed that the difference was not significant ( $p=0.599)$. The mean dose of misoprostol in the OMS group was 4 times higher than the PV, but it is reasonable from the standpoint of drug pharmacodynamics.

All subjects $(100 \%)$ in the OMS group reached in labour $\leq 12$ hours, while the PV group had one subject $(6.7 \%)$ with failed induction. The diagnosis of the subject who had a failed induction by vaginal misoprostol is a post-termpregnancy (gestational age 41-42 weeks). This particular subject was induced with IV oxytocin and managed to achieve spontaneous labor. The use of oxytocin in the OMS group is less than the PV group. All subjects in the PV group achieved spontaneous delivery, whereas in the OMS group there is 1 subject (7.1\%) who needed abdominal termination due to prolonged latent phase and 1 subject (7.1\%) terminated by forceps extraction due to maternal ventricular septal defect.

Table 1. Characteristics of the Subjects

\begin{tabular}{|c|c|c|c|c|c|}
\hline \multirow{2}{*}{ Variables } & \multicolumn{2}{|c|}{ OMS } & \multicolumn{2}{|c|}{ PV } & \multirow{2}{*}{ p value } \\
\hline & $\mathbf{n}$ & $\%$ & $\mathbf{n}$ & $\%$ & \\
\hline Mean maternal age (years) & $28.64 \pm 6.54$ & $30.67 \pm 6.14$ & $0.397^{*}$ & & \\
\hline Mean gestational age (weeks) & $37.79 \pm 2.36$ & $38.67 \pm 27.9$ & $0.369 *$ & & \\
\hline Mean Bishop score & $3.57 \pm 1.02$ & $3.40 \pm 0.99$ & $0.648^{*}$ & & \\
\hline \multicolumn{6}{|l|}{ Bishop score } \\
\hline$\leq 4$ & 7 & 50 & 8 & 53.3 & 1.000 \\
\hline $5-6$ & 7 & 50 & 7 & 46.7 & $* *$ \\
\hline \multicolumn{6}{|l|}{ Body mass index } \\
\hline Nonobese (18-24.9) & 3 & 21.4 & 4 & 26.7 & 1.000 \\
\hline Obese $(\geq 25)$ & 11 & 78.6 & 11 & 73.3 & $* * *$ \\
\hline \multicolumn{6}{|l|}{ Parity } \\
\hline Nullipara & 9 & 64.3 & 8 & 53.3 & 0.825 \\
\hline Multipara & 5 & 35.7 & 7 & 46.7 & $* *$ \\
\hline \multicolumn{6}{|l|}{ Induction indication } \\
\hline Preeclampsia & 5 & 35.7 & 6 & 40 & \\
\hline Postterm/postdate & 0 & 0 & 4 & 26.7 & \\
\hline Oligohidramnion & 4 & 28.5 & 2 & 13.3 & 0.145 \\
\hline PROM & 2 & 14.2 & 2 & 13.3 & $* * * *$ \\
\hline Others & 3 & 21.4 & 1 & 6.7 & \\
\hline
\end{tabular}

* Unpaired T-test; $p=0.05$

** Chi-square test

*** Fischer exact test

****Pearson correlation test 
Table 2. Labour Outcome Characteristics

\begin{tabular}{|c|c|c|c|c|c|}
\hline \multirow{2}{*}{ Variables } & \multicolumn{2}{|c|}{ OMS } & \multicolumn{2}{|c|}{ PV } & \multirow{2}{*}{ p value } \\
\hline & $\mathbf{n}$ & $\%$ & $\mathbf{n}$ & $\%$ & \\
\hline Induction-inlabour interval (hours) & $5.75 \pm 6.54$ & $6.60 \pm 4.46$ & $0.560^{*}$ & & $*$ \\
\hline Induction-active phase interval (hours) & $7.25 \pm 2.36$ & $8.07 \pm 5.53$ & $0.686^{*}$ & & \\
\hline Induction-delivery interval (hours) & $10.11 \pm 1.02$ & $11.33 \pm 6.24$ & $0.599 *$ & & \\
\hline Total misoprostol dose ( $\mu \mathrm{g})$ & $218.57 \pm 147.27$ & $50.00 \pm 23.15$ & & & \\
\hline \multicolumn{6}{|l|}{ Vaginal delivery $\leq 12$ hours } \\
\hline Yes & 9 & 64.3 & 10 & 66.7 & 1.000 \\
\hline No & 5 & 35.7 & 5 & 33.3 & $* *$ \\
\hline \multicolumn{6}{|l|}{ Vaginal delivery $\leq 24$ hours } \\
\hline Yes & 13 & 92.9 & 15 & 100 & 0.483 \\
\hline No & 1 & 7.1 & 0 & 0 & $* * *$ \\
\hline \multicolumn{6}{|l|}{ Oxytocin acceleration } \\
\hline Yes & 5 & 35.7 & 6 & 40 & 1.000 \\
\hline No & 9 & 64.3 & 9 & 60 & ** \\
\hline \multicolumn{6}{|l|}{ Failed induction } \\
\hline Yes & 0 & 0 & 1 & 6.7 & 1.000 \\
\hline No & 14 & 100 & 14 & 93.3 & $* * *$ \\
\hline \multicolumn{6}{|l|}{ Delivery type } \\
\hline Spontaneous & 12 & 85.7 & 14 & 93.3 & \\
\hline Operative & 1 & 7.1 & 0 & 0 & 0.316 \\
\hline vaginal & & & & & $* * * *$ \\
\hline Abdominal & 1 & 7.1 & 0 & 0 & \\
\hline
\end{tabular}

* Unpaired T-test; $p=0.05$

** Chi-square test

*** Fischer exact test

****Pearson correlation test

Table 3. Maternal and Neonatal Outcome Characteristics

\begin{tabular}{|c|c|c|c|c|c|}
\hline \multirow{2}{*}{ Variables } & \multicolumn{2}{|c|}{ OMS } & \multicolumn{2}{|c|}{ PV } & \multirow{2}{*}{ p value } \\
\hline & $\mathbf{n}$ & $\%$ & $\mathbf{n}$ & $\%$ & \\
\hline \multicolumn{6}{|c|}{ Hyperstimulation } \\
\hline Yes & 1 & 7.1 & 1 & 6.7 & $1.000^{*}$ \\
\hline \multirow[t]{2}{*}{ No } & 1 & 92.9 & 14 & 93.3 & \\
\hline & 3 & & & & \\
\hline \multicolumn{6}{|c|}{ Tachysystolic uterus } \\
\hline Yes & 0 & 0 & 1 & 6.7 & $1.000^{*}$ \\
\hline \multirow[t]{2}{*}{ No } & 1 & 100 & 14 & 93.3 & \\
\hline & 4 & & & & \\
\hline \multicolumn{6}{|c|}{ Uterine rupture } \\
\hline Yes & 0 & 0 & 0 & 0 & $1.000^{*}$ \\
\hline \multirow[t]{2}{*}{ No } & 1 & 100 & 15 & 10 & \\
\hline & 4 & & & 0 & \\
\hline \multicolumn{6}{|c|}{ Postpartum hemorrhage } \\
\hline Yes & 0 & 0 & 0 & 0 & $1.000^{*}$ \\
\hline \multirow[t]{2}{*}{ No } & 1 & 100 & 15 & 10 & \\
\hline & 4 & & & 0 & \\
\hline
\end{tabular}




\begin{tabular}{|c|c|c|c|c|c|}
\hline \multirow{2}{*}{ Variables } & \multicolumn{2}{|c|}{ OMS } & \multicolumn{2}{|c|}{ PV } & \multirow{2}{*}{$p$ value } \\
\hline & $\mathbf{n}$ & $\%$ & $\mathbf{n}$ & $\%$ & \\
\hline \multicolumn{6}{|l|}{ Shivering } \\
\hline Yes & 4 & 28.6 & 6 & 40 & $0.700 *$ \\
\hline \multirow[t]{2}{*}{ No } & 1 & 71.4 & 9 & 60 & \\
\hline & 0 & & & & \\
\hline \multicolumn{6}{|l|}{ Fever } \\
\hline Yes & 0 & 0 & 0 & 0 & $1.000 *$ \\
\hline \multirow[t]{2}{*}{ No } & 1 & 100 & 15 & 10 & \\
\hline & 4 & & & 0 & \\
\hline \multicolumn{6}{|l|}{ Nausea } \\
\hline Yes & 1 & 7.1 & 0 & 0 & $0.483^{*}$ \\
\hline \multirow[t]{2}{*}{ No } & 1 & 92.9 & 15 & 10 & \\
\hline & 3 & & & 0 & \\
\hline \multicolumn{6}{|l|}{ Vomiting } \\
\hline Yes & 1 & 7.1 & 0 & 0 & $0.483^{*}$ \\
\hline \multirow[t]{2}{*}{ No } & 1 & 92.9 & 15 & 10 & \\
\hline & 3 & & & 0 & \\
\hline \multicolumn{6}{|l|}{ Diarrhea } \\
\hline Yes & 0 & 0 & 0 & 0 & $1.000^{*}$ \\
\hline \multirow[t]{2}{*}{ No } & 1 & 100 & 15 & 10 & \\
\hline & 4 & & & 0 & \\
\hline \multicolumn{6}{|c|}{ Meconium staining } \\
\hline Yes & 6 & 42.9 & 5 & 33.3 & $0.885^{*}$ \\
\hline No & 8 & 57.1 & 10 & 66.7 & \\
\hline \multicolumn{6}{|c|}{ Fetal distress } \\
\hline Yes & 1 & 7.1 & 0 & 0 & $0.483^{*}$ \\
\hline No & 13 & 92.9 & 15 & 100 & \\
\hline \multicolumn{6}{|c|}{ APGAR score at $1 \mathrm{~min}$} \\
\hline$<8$ & 3 & 21.4 & 3 & 20 & $1.000^{*}$ \\
\hline$\geq 8$ & 11 & 78.6 & 12 & 80 & \\
\hline \multicolumn{6}{|c|}{ APGAR score at $5 \mathrm{~min}$} \\
\hline$<8$ & 2 & 14.3 & 2 & 13.3 & $1.000^{*}$ \\
\hline$\geq 8$ & 12 & 85.7 & 13 & 86.7 & \\
\hline \multicolumn{6}{|c|}{ NICU admission } \\
\hline Yes & 1 & 7.1 & 2 & 13.3 & $1.000 *$ \\
\hline No & 13 & 92.9 & 13 & 86.7 & \\
\hline \multicolumn{6}{|c|}{ Perinatal death } \\
\hline Yes & 0 & 0 & 1 & 6.7 & $1.000^{*}$ \\
\hline No & 14 & 100 & 14 & 93.3 & \\
\hline
\end{tabular}

Table 3 shows maternal and neonatal outcomes on the use of drugs in both groups. There were no significant differences in maternal outcome variables between the two groups. In the OMS group of, there is one subject (7.1\%) who developed uterine hyperstimulation following administration of oral misoprostol $480 \mathrm{ml}$ within
11 hours. The induction on this particular subject is antepartum eclampsia. While in the PV group, there is one subject (6.7\%) who developed uterine hyperstimulation following administration of vaginal misoprostol $75 \mathrm{mg}$ in 12 hours and 1 subject $(6.7 \%)$ with a tachysystole uterus. The induction indications of these subjects were fetal 
congenital abnormality and preeclampsia respectively. Subjects from the PV group complained more chills (40\%) than the OMS group (28.6\%). Misoprostol was immediately discontinued in case of uterine hyperstimulation and tachysystole uterus. Furthermore, patients were given $10 \mathrm{mg}$ of nifedipine and fetal heartbeats were monitored closely. Neonatal outcomes are relatively similar in both groups. Fetal distress was found in 1 subject $(7.1 \%)$ with a gestational age of 31 weeks and an indication of antepartum eclampsia, which received OMS. Fetal distress occurs during the active phase due to hypoxia.

All subjects $(100 \%)$ in the OMS group reached inlabour $\leq 12$ hours, while 14 subjects $(93.3 \%)$ of the PV group reached inlabour $\leq 12$ hours. There were no efficacy differences between oral titrated solution misoprostol with vaginal misoprostol in achieving inlabour $\leq 12$ hours $(\mathrm{p}=1.000)$. Furthermore, this study resulted with a cut-off point of induction-inlabour interval at 4.75 hours. Based on the cut-off point, there were no differences between the oral misoprostol and vaginal misoprostol groups $(p=1.000, p>0.05)$.

\section{DISCUSSION}

The study found no significant differences of mean age, mean gestational age, mean Bishop score, parity, and induction indications of labor between the two groups. The most common indication of labor induction is hypertension in pregnancy. A study by Rouzi, Madhavi, and Cheng also had similar results, but the most common indication in their study was post-term pregnancy. The third study was an RCT designs, but single blinded. The inclusion criteria between these studies were similar; Rouzi and Cheng used an inclusion criteria of 34-42 weeks' gestation; while Madhavi examined only 38-41 weeks gestation term. Furthermore, Madhavi used 60 samples, Rouzi used 160 samples, Rouzi and Cheng used a larger sample size of 207 samples. $^{5-8}$

The study also found no significant difference between the mean induction-inlabour and induction-labor intervals between groups. The mean induction-inlabour interval in the OMS group were $5.75 \pm 3.14$ hours and $6.60 \pm 4.46$ hours in the PV group. Rouzi, et al. also failed to observe a significant difference in the inductionin labour interval. In his study, the mean induction-labor interval in the OMS group was $17.6 \pm 8.5$ hours and $20.2 \pm 18$ hours in the PV group. ${ }^{5}$ Madhavi also found no significant differences in induction to delivery interval between OMS and and PV groups. The mean induction-labor ineterval in the OMS group was 13.83 hours and 13.82 hours in PV group $(\mathrm{p}=0.994){ }^{8}$

Conversely, Cheng, et al. obtained significant difference of intervals until labor between OMS and PV groups. The mean induction - vaginal delivery interval was 8.2 hours in the OMS group and 17.6 hours in the PV group ( $\mathrm{p}<0.01)$. The latent phase was 6.5 hours in the OMS group and 13.4 hours in the PV group; while the active phase was 1.6 hours in the OMS group and 3.4 hours in the PV group ( $p<0.01)^{6,7}$ In contrast to these results, Ashalatha observed a significant difference in mean induction - labor interval in both groups. According to Ashalatha, vaginal misoprostol has a shorter induction - labor interval shorter compared with oral titrated misoprostol, with 17.8 hours in the PV group and 27.9 hours in the OMS group, with a mean difference of 10.1 hours. $^{9}$ The study by Cheng had inclusion criterias and study protocols that were almost similar to this study, but the large number of samples resulted in significant differences regarding the effectiveness between the two groups. Ashalatha, et al. used misoprostol dose titration per hour, but with a larger sample size of 245 samples. Madhavi used a protocol of OMS dose per 2 hours with a small sample size (n $=60$ ), and the results were similar to the results of this study. Differences in failed induction criterias may also lead to a diversity of results. Factors such as infection, sweeping of the membrane, and amniotomy were also not controlled in this study.

The mean dose of misoprostol in the PV group is lower than the OMS group. This is due to the pharmacokinetics of misoprostol, which is different for each route of administration. Onset of action of oral misoprostol started at 8 minutes, a maximum half-life at 30 minutes, and a duration of 2 hours. When administered vaginally, the onset of action of misoprostol begins after 20 minutes of administration, the half-life of up to 70 minutes, and a duration of 4 hours. Therefore, vaginal misoprostol remains effective for a longer time and the total dose required for induction of labor is lower. ${ }^{10}$ 
This study did not observe any oxytocin acceleration incidence difference between the two groups. Acceleration oxytocin were indicated in 5 subjects $(35.7 \%)$ in the OMS group and 6 (40\%) in the PV group. Madhavi also obtain similar results. In the study by Madhavi, $26.7 \%$ of the subjects in the OMS group and $20 \%$ of the subjects in the PV group required oxytocin acceleration $(p=0.542){ }^{8}$ Conversely, Cheng, et al. only found $10.9 \%$ of the subjects in the OMS group of CSOs who required oxytocin. This percentage is much less than 53.8\% of the subjects in the PV group that required oxytocin acceleration $(p=0.01) .6$ Another study by Ashalatha found that fewer oxytocin acceleration were indicated in the PV group (39\%) compared to OMS (58.2\%) group. ${ }^{10}$

In this study, all subjects in the PV intervention group is treated by spontaneous labor. Whereas in the OMS group, spontaneous labor occured in 12 subjects (85.7\%), extraction forceps and cesarean section respectively in 1 subject (7.1\%). Indication for forceps extraction is maternal cardio decompensation with a ventricular septal defect, so it is actually not related to the labor disruption at the second stage. Indication of cesarean section on the subject of this study is prolonged latent phase. There were no significant differences regarding the type of delivery between the OMS and PV groups according to Madhavi $(\mathrm{p}=0.43) .{ }^{8}$ Cheng, et al. also concluded that the incidence of uterine hyperstimulation and cesarean sections are lower when misoprostol is administered orally in titrated solution. 6

The study found no differences in maternal outcomes between the two groups. Uterine hyperstimulation was found in one subjects with a diagnosis of $\mathrm{P}_{3} \mathrm{G}_{4} \mathrm{~A}_{0} 31$ weeks pregnant with antepartum eclampsia, single live fetus and head presentation in the OMS group, which then reached the active phase. Uterine hyperstimulation was managed with fetal resuscitation, administration of nifedipine, and planned abdominal termination. But in the preparatory period of operation, the subject reached the second stage of labour. The fetus was born spontaneously with only 1400 grams birth weight and an Apgar score of 3/5/7. After undergoing intensive care in the NICU for 21 days, the baby's condition is healthy and stable. Nausea, vomiting, and shivering were quite observable symptoms which disappears after two hours of observation. Uterine hyperstimulation in the PV group was found in one subject a diagnosis of $G_{1} P_{0} A_{0}$, pregnant for 31 weeks, single live fetus with a head presentation + polyhydramnios + congenital abnormalities (there are findings of deformities of the heart, spinal deformity, single umbilical artery, echogenic bowel, hydrocele, ascites and claw hand) with a biophysical profile score of 8 . When uterine hyperstimulation occured, the subject had reached $6 \mathrm{~cm}$ cervical dilatation and the fetus experienced tachycardia. Approximately 10 minutes after hyperstimulation of the uterus, the fetus is born spontaneously with 1 minute Apgar score of 1 , and 5 minutes later the fetus died. The cause of perinatal death in this case is likely due to major congenital abnormalities. Madhavi only found 1 subject (3.3\%) in the PV group who experienced uterine hyperstimulation and was treated by administration of terbutaline 250 mcg via subcutaneous injection. Misoprostol side effects such as nausea, vomiting, diarrhea, and fever were not found in the study by Madhavi. ${ }^{8}$ Cheng et al. reported that oral and vaginal misoprostol are equally safe for the mother. Cheng reported misoprostol mild side effects such as nausea (10.9\%), vomiting (8.9\%), and diarrhea (5\%) in the OMS group. ${ }^{6}$

In the OMS group, there were 6 cases of thick meconium staining. While in PV group, there were 5 cases of thick meconium staining. This incident may be triggered by the high-risk pregnancies, such as post-term pregnancy accompanied by oligohydramnios, premature rupture of membranes more than one day, and preeclampsia/ eclampsia. Madhavi reported 2 cases (6.7\%) of thick meconium staining in the OMS group and 2 cases $(6.7 \%)$ in the PV group. Both cases of thick meconium staining in the OMS group underwent cesarean sections, where the first case were caused by a non-reassuring CTG and the other cases by arrest of labor. In the PV group, two cases with thick meconium staining underwent cesarean section due to non-reassuring CTG. The four neonates in the study by Madhavi did not require NICU care and did not experienced respiratory failure syndrome. ${ }^{8}$ The same was reported by Ashalatha, where the incidence of thick meconium staining is more common in oral compared to vaginal misoprostol. ${ }^{9}$ In this study, we observed one neonate from the OMS group who needed NICU treatement, where the gestation age was 31 weeks, the fetus is born prematurely with low birth weight (1400 grams), and the newborn developed respiratory failure syndrome. While in 
PV group, there are two neonates who required NICU care. One case was treated in the NICU because of a congenital heart defect, and the other due to respiratory failure syndrome.

There were no differences in the efficacy of oral titrated misoprostol solution and vaginal misoprostol in achieving inlabour $\leq 12$ hours. Similar results were also obtained from the study by Madhavi. Madhavi concluded that administration of oral and vaginal misoprostol has the same effectiveness for labor induction. ${ }^{8}$ Zvandasara et al. conducted a similar research at the University Hospital of Zimbabwe involving 69 pregnant women in the 0|MS group and 65 pregnant women in the PV group. The study concluded that the effectiveness and safety of OMS is similar with PV for induction of labor, even in poor countries where intrapartum supervision is often inadequate. Subjects induced by OMS have a faster induction- initiation of uterine contraction interval $(\mathrm{OR}=0.94 ; 95 \% \mathrm{CI}=0.42-2.12)$, but with a longer duration of labor (OR, 0.36; 95\% CI 0,16-0.79). Acceleration of oxytocin were more common in the OMS group. ${ }^{11}$ In contrast, Cheng, et al. reported that oral titrated misoprostol may furtherly shorten the interval from induction to vaginal delivery compared to vaginal administration. In addition, the percentage of vaginal delivery $\leq 12$ hours were more common in the OMS group compared to $\mathrm{PV}(\mathrm{p}=0.01, \mathrm{RR}=8.44$ [4.52 to 15.76]). The percentage of vaginal delivery $\leq 24$ hours are also more common in the OMS compared to $\mathrm{PV}$; with a $p$-value $=0.01$ and RR 13.61 (5.49 to 33.78). Failed induction is more common in PV group. ${ }^{6}$

This study is a double blind RCT-add on, thus ensuring the strength of the end results. Randomization in this study aims to create similar characteristics between groups. This study also conducted a double-blinding, where researchers and survey respondents did not know the status of the respondent whether they were included in the intervention or non-intervention group. The strength of this design can minimize confounding factors that may lead to bias in the results. Placebo used in this study is made of starch which is inert, does not have a pharmacological effect, and mimics the appearance, taste, and smell of misoprostol (Cytotex). The weakness of this study is the small sample size of just 30 people, thus resulting in the possibility of low precision. In addition, several confounding factors that can accelerate the onset of labor such as infection, sweeping of the membrane, and amniotomy were also not controlled in this study.

\section{CONCLUSION}

Oral titrated misoprostol in solution and vaginal misoprostol are equally effective for achieveing in labour within 12 hours. There was no difference in maternal and neonatal outcome of labour in both the groups.

\section{REFERENCES}

1. Norwitz E, Robinson J, Repke J. Labor and delivery. In: Gabbe SG, Niebyl JR, Simpson JL, eds. Obstetrics: normal and problem pregnancies. $4^{\text {th }}$ ed. New York: Churchill Livingstone, 2002: 353-94.

2. MacKenzie IZ. Induction of labour at the start of the new millennium. Reprod. 2006; 131: 989-98.

3. Vogel JP, Souza JP, Gulmezoglu AM. Patterns and outcomes of induction of labour in Africa and Asia: A secondary analysis of the WHO global survey on maternal and neonatal health. Plos One. 2013; 8(6): e65612-23.

4. McCarthy FP, Kenny LC. Induction of labour. Obstet Gynecol Reprod Med. 2013; 24(1): 9-15.

5. Rouzi AA, Alsibiani SA, Mansouri N, Alsinani N, Darhouse K. Randomized clinical trial between hourly titrated oral misoprostol and vaginal dinoprostone for induction of labor. Am J Obstet Gynecol. 2014; 210: 56.e1-6.

6. Cheng SY, Ming H, Lee JC. Titrated oral compared with vaginal misoprostol for labor induction. Obstet Gynecol. 2008; 111(1): 119-25.

7. Cheng SY. Individualized misoprostol dosing for labor induction or augmentation: A review. World J Obstet Gynecol. 2013; 2(4): 80-6.

8. Madhavi. A comparative study of titrated low dose oral misoprostol versus vaginal misoprostol for induction of labour at term. Journal of Rajiv Gandhi University. 2009. Available at www.rguhs.ac.in/cdc/onlinecdc/uploads/01_M029_117 00.doc

9. Ashalatha S, Danielian P, Templeton A. A comparison of oral and vaginal misoprostol tablets in induction of labour at term. British J Obstet Gynecol. 2001; 108: 238-43.

10. Tang OS, Gemzell-Danielsson K, Ho PC. Misoprostol: Pharmacokinetics profiles, effects on the uterus, and side-effects. Int J Gynecol Obstet. 2007; 99: s160-7.

11. Zvandasara P, Saungweme G, Mlambo J, Chidembo W, Madzivanzira N, Mwanjira C. Induction of labour with titrated oral misoprostol suspension: a comparative study with vaginal misoprostol. Cent Afr J Med. 2008; 54(9-12): 43-9. 